\title{
Frohe Weihnachten und ein gutes neues Jahr! Joyeux Noël et bonne année!
}

Die Berater der FMH Insurance Services danken Ihnen für Ihr Vertrauen und wünschen Ihnen frohe Festtage.

Les conseillers FMH Insurance Services vous remercient de la confiance témoignée et vous souhaitent de joyeuses fêtes de fin d'année.
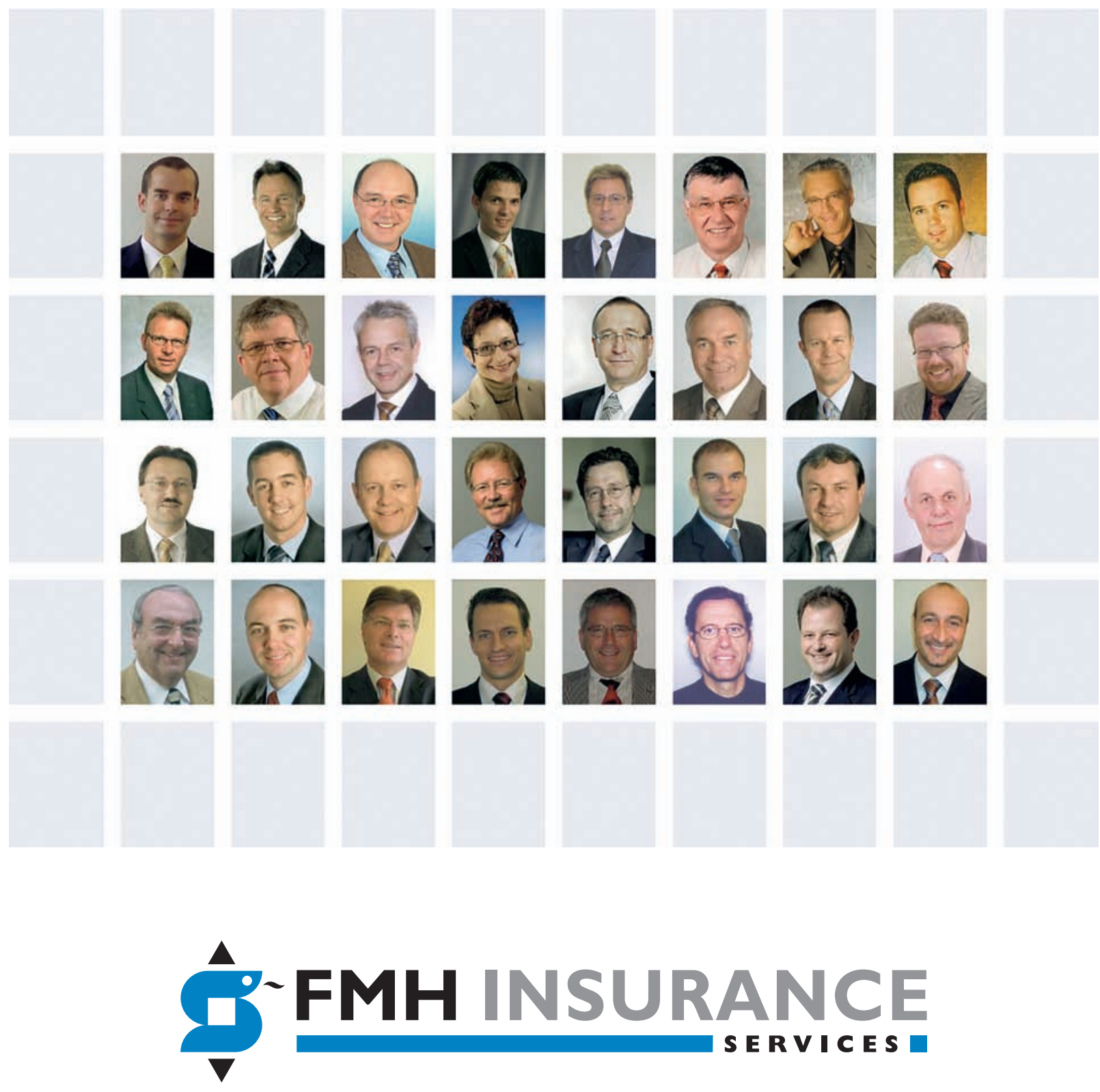